\title{
Temporal dynamics of fish assemblages of natural and artificial tropical estuaries
}

\author{
Marcus Sheaves ${ }^{1, *}, \operatorname{Ross}$ Johnston $^{1}, \operatorname{Rod}$ M. Connolly ${ }^{2}$ \\ ${ }^{1}$ Coastal and Estuarine Ecosystems Laboratory, School of Marine and Tropical Biology, James Cook University, Townsville, \\ Queensland 4811, Australia \\ ${ }^{2}$ Australian Rivers Institute - Coast and Estuaries, and School of Environment, Griffith University, Gold Coast, \\ Queensland 4222, Australia
}

\begin{abstract}
We sampled the fish fauna of 9 small natural estuaries and 2 constructed estuarine lakes in Australia's dry tropics over 15 mo to detail the dynamics of fish assembly structures over time. The estuaries chosen were small enough that the cast net sampling method which we used could cover the full extent of the estuary, obviating the problem that within-estuary migration might lead to the false appearance of assemblage change over time. Temporal patterns in assemblage structure were consistent across the natural estuaries, overprinting complex spatial differences. Nursery ground utilisation and assemblage composition were intimately interlinked. In natural estuaries, assemblage change was a function of changes in both probability of encounter of individual species and in species compositions, and the recruitment, growth and subsequent emigration from the estuaries of juveniles was the main contributor to overall assemblage change. In contrast, in artificial lakes where connectivity with offshore sources of recruits was restricted, species compositions were attenuated and temporal change was not driven by the recruitment of offshore species.
\end{abstract}

KEY WORDS: Estuary · Tropics · Fish · Assemblage structure $\cdot$ Temporal dynamics · Connectivity

\section{INTRODUCTION}

Our understanding of the large- (Ley 2005) and mesoscale (Sheaves 1996a, Johnston \& Sheaves 2008) spatial patterns of tropical estuarine fish assemblages has slowly increased over time. In contrast, there have been few attempts to systematically study the temporal dynamics of these assemblages, and those which have been made have usually been limited in temporal resolution, and have provided only coarse-scale temporal information (Sheaves 2006), or fine detail confined to a single estuary system (Robertson \& Duke 1990a). Other studies that have included a temporal component have been primarily concerned with spatial factors (Blaber et al. 1989, Sheaves 1998), physical factors (Cyrus \& Blaber 1992, Sheaves 1996b), attributes of estuaries (Ley 2005), or fisheries management status (Ley et al. 2002).

Robertson \& Duke (1990a) made a detailed temporal assessment of the fish assemblage of Alligator Creek in tropical eastern Australia. They found catch per unit effort (CPUE) peaked in the pre-wet and wet seasons, driven by an influx of juveniles of offshore species that used the estuary as a nursery ground. Thus, at least in Alligator Creek, the annual recruitment of offshore juveniles was a key driver of assemblage change over time, a finding consistent with studies from the Gulf of Mexico (Deegan 1993, Rozas et al. 2007), Florida (Greenwood et al. 2007) and Portugal (Ramos et al. 2006). A less temporally resolved (only dry versus wet season) study of 9 tropical Australian estuaries (Sheaves 2006) found dry versus wet season faunal differences consistent with the results of Robertson \& Duke (1990a). While more spatially extensive at one scale, in that it included 9 estuaries, Sheaves (2006) only considered the extreme downstream reaches of the estuaries, and so did not provide information on system-wide change. Robertson \& Duke's (1990a) study suffered a similar limitation as sampling was 
confined to selected sections of the estuary. Consequently, it is unclear if the importance of juveniles of offshore species in driving seasonal change in fish assemblages, which was apparent in Alligator Creek (Robertson \& Duke 1990a), is a general feature of tropical Australian estuaries.

Globally, developing a general understanding of the key drivers of seasonal change in estuarine assemblage structure is critical in linking pattern and process, and is central to resolving a spectrum of ecological questions. For instance, it is likely to be a crucial factor generating differences in assemblage structure at the estuary-to-estuary scale (Ley 2005, Greenwood et al. 2007, Sheaves \& Johnston 2009). Understanding temporal change in assemblage structure is also essential to the developing understanding of estuarine food webs (Deegan 1993), particularly for tropical systems that undergo complex seasonal (Robertson \& Duke 1990a, Abrantes 2008) and spatial change (Abrantes \& Sheaves 2008), and where trophic roles vary over ontogeny (Wilson \& Sheaves 2001). It is also fundamental to the development of monitoring protocols in tropical estuaries, where understanding estuary-specific change is critical in assessing impact (Sheaves \& Johnston 2010).

The current study was undertaken to determine the extent to which the results of Robertson \& Duke (1990a) are representative of estuaries in tropical northern Australia. In particular, the study aimed (1) to detail the dynamics of fish assembly structures over time, (2) to determine the consistency of temporal change among estuaries, and (3) to determine the relative contribution of offshore and estuary spawners to temporal and spatial patterns in assemblage structure. The research was conducted in 9 small natural estuaries and 2 constructed estuarine lakes over 15 mo. Small estuaries were used to ensure that the whole estuary could be sampled, thus minimising variability due to within-estuary migration. The 2 constructed estuarine lakes had limited connectivity to sources of recruits, and were included to allow assessment of change where the influence of recruitment was limited.

\section{MATERIALS AND METHODS}

Study sites. The study was conducted between November 2007 and January 2009 in 9 small (maximum $8 \mathrm{~km}$ navigable length) natural estuaries and 2 constructed estuarine lakes in dry tropical north Queensland, Australia, spanning approximately $225 \mathrm{~km}$ of coastline (Fig. 1). The natural estuaries are typical of the region. The width at the mouth varied between 40 and $100 \mathrm{~m}$ but within about $250 \mathrm{~m}$ all narrowed to a maximum width of about $30 \mathrm{~m}$. Maximum depth was

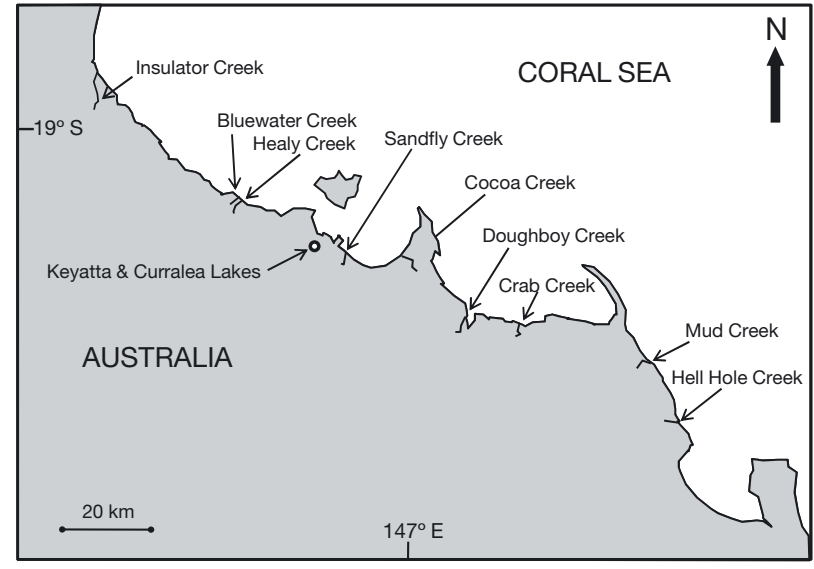

Fig. 1. Location of the 11 study estuaries in northeastern Australia

approximately $3.5 \mathrm{~m}$ in downstream reaches at low tide, and all estuaries became increasingly shallow with distance upstream, with only a few centimetres of water remaining at low tide upstream of the limits of navigation. All estuaries were mangrove lined for most of their length, with extensive saltmarsh (dominated by Sporobolus virginicus and/or succulents) and saltpan bordering the landward margins of mangrove forests and occurring on higher stream banks. The 2 constructed estuarine lakes, Keyatta and Curralea Lakes, are in the centre of Townsville, north Queensland, Australia (Fig. 1). Keyatta Lake has restricted tidal connection to the estuary of Ross Creek via a $1.7 \mathrm{~km}$ long concrete channel. Curralea Lake's only tidal connection is through a $100 \mathrm{~m}$ long channel to Keyatta Lake.

The regional rainfall pattern features 4 key periods: (1) a distinct but variable hot wet season through January and February (but variably extending into late December or early March); (2) an extended dry period comprising a post-wet season (March to May), when the weather cools but some rainfall may occur; (3) a cool dry season (June to September), and; (4) a pre-wet season (October to December), when the weather begins to warm but little rain falls. The 2 wet seasons during the study were unusually intense, with $1047 \mathrm{~mm}$ of rainfall recorded between late January and February 2008, and $1615 \mathrm{~mm}$ during January and February 2009 (wet season average $586 \mathrm{~mm}$ ) at the Townsville weather station (BOM 2009), making these, respectively, the 9th highest and 2nd highest wet season totals since records began in 1940. Tides in the region are semi-diurnal with a maximum range of about $4 \mathrm{~m}$.

Sampling. Initially, monthly sampling was planned; however, flooding prevented access to some or all sites each month between December 2007 and March 2008. Preliminary evaluation of samples up to May 2008 
indicated bi-monthly sampling would be sufficient to represent change in assemblage structure and in the major species. Consequently, the sampling frequency was reduced to bi-monthly to reduce the number of fish that were collected (Table 1); however, additional samples were collected from Crab, Doughboy and Hell Hole Creeks in October and December 2008 to allow detection of the timing of the start of the summer recruitment season. Sampling was again disrupted by severe flooding during December 2008 and January 2009.

Small estuaries were selected so that sampling could be conducted over the whole estuary system within 1 low tide cycle, with the aim of ensuring that species present would be consistently represented, regardless of the extent to which they moved within the system. In each estuary, samples were collected haphazardly over the full upstream extent navigable in the $4.3 \mathrm{~m}$ aluminium dingy used for sampling. Sampling sites were allocated to represent all habitat types accessible using the sampling gear, approximately in proportion to their linear extent. To allow the detection of any within-estuary spatial differences, the 7 larger natural estuaries (Insulator, Sandfly, Cocoa, Doughboy, Crab, Mud, and Hell Hole Creeks) were each divided into 3 reaches (downstream, mid, upstream) and equal numbers of samples collected from each. Initially, 90 samples were collected from each of the large estuaries, but this was reduced to 45 on each subsequent occasion because preliminary analysis indicated that this provided adequate representation. Thirty and 20 samples respectively were collected from Healy $(1.8 \mathrm{~km}$ long) and Bluewater (0.8 km long) Creeks, the 2 shortest natural estuaries, and 30 samples were taken from each artificial lake, Curralea and Keyatta.

Sampling was conducted using small mesh monofilament drawstring cast nets $(2.4 \mathrm{~m}$ radius with $5 \mathrm{~mm}$ mesh) because this gear type could be used across the greatest range of habitats in the sampling area (Johnston \& Sheaves 2008) while producing the widest taxonomic and size representation possible (Sheaves et al. 2007). Although the present study probably provided good representation of the small and juvenile components that make up the bulk of fish in tropical estuarine assemblages (Blaber 1980, Robertson \& Duke 1990b), larger mobile species were likely to be underrepresented (Sheaves \& Johnston 2009); consequently, this study focuses on the small and juvenile component of the fauna. Cast nets operated by the same individual were used for all nekton collection. Samples were collected from a $4.3 \mathrm{~m}$ dinghy, fitted with an electric motor to reduce potential for disturbance, and followed the protocols set out by Sheaves et al. (2007). Samples were collected over the lower half of the tide, when small fish are forced out of the mangroves into the main channel of the estuary. Sampling was concentrated along the banks of the estuaries because these areas contain the bulk of small fish throughout most of the lower part of the tidal cycle (Johnston \& Sheaves 2008). Fish less than $5 \mathrm{~mm}$ body depth were excluded from analyses because these were below mesh selection size and so unlikely to be well represented in samples.

Statistical analysis. Statistical analyses were based on probability of encounter (PoE), i.e. presences per net, rather than CPUE. This approach has proved robust for cast net samples from tropical estuaries (Sheaves \& Johnston 2009) because it treats species with a diversity of behaviours and patterns of spatial distribution in a more equivalent way than fully quantitative techniques (Manley et al. 2004). The dependent variable for all analyses was the number of nets in each Estuary $\times$ Trip $\times$ Reach combination in which a species occurred, and explanatory variables were Estuary,

Table 1. Sampling sites and times (season in brackets). Crosses indicate sampling occasions; bold crosses indicate the 4 estuary sequences used for detailed analyses of temporal change. Gaps: no sample collected

\begin{tabular}{|c|c|c|c|c|c|c|c|c|c|c|c|c|}
\hline Location & $\begin{array}{c}\text { Nov } \\
2007 \\
\text { (pre-wet) }\end{array}$ & $\begin{array}{l}\text { Dec } \\
2007 \\
\text { (wet) }\end{array}$ & $\begin{array}{c}\text { Mar } \\
2008 \\
\text { (post-wet) }\end{array}$ & $\begin{array}{c}\text { Apr } \\
2008 \\
\text { (post-wet) }\end{array}$ & $\begin{array}{c}\text { May } \\
2008 \\
\text { (post-wet) }\end{array}$ & $\begin{array}{c}\text { Jul } \\
2008 \\
\text { (dry) }\end{array}$ & $\begin{array}{l}\text { Sep } \\
2008 \\
\text { (dry) }\end{array}$ & $\begin{array}{c}\text { Oct } \\
2008 \\
\text { (pre-wet) }\end{array}$ & $\begin{array}{c}\text { Nov } \\
2008 \\
\text { (pre-wet) }\end{array}$ & $\begin{array}{c}\text { Dec } \\
2008 \\
\text { (pre-wet) }\end{array}$ & $\begin{array}{c}\text { Jan } \\
2009 \\
\text { (wet) }\end{array}$ & $\begin{array}{l}\text { Total } \\
\text { nets }\end{array}$ \\
\hline Bluewater Creek & $\mathrm{x}$ & & $\mathrm{x}$ & $\mathrm{x}$ & $\mathrm{x}$ & $\mathrm{x}$ & $\mathrm{x}$ & & $\mathrm{x}$ & & & 143 \\
\hline Cocoa Creek & $\mathbf{X}$ & $\mathbf{X}$ & $\mathbf{X}$ & $\mathbf{X}$ & $\mathbf{X}$ & $\mathbf{X}$ & $\mathbf{X}$ & & $\mathbf{X}$ & & $\mathbf{X}$ & 435 \\
\hline Crab Creek & $\mathbf{X}$ & $\mathbf{X}$ & $\mathbf{X}$ & $\mathbf{X}$ & $\mathbf{X}$ & $\mathbf{X}$ & $\mathbf{X}$ & $\mathbf{X}$ & $\mathbf{X}$ & $\mathbf{X}$ & $\mathbf{X}$ & 525 \\
\hline Curralea Lake & $\mathrm{x}$ & $\mathrm{x}$ & $\mathrm{x}$ & $\mathrm{x}$ & $\mathrm{x}$ & $\mathrm{x}$ & $\mathrm{x}$ & & $\mathrm{x}$ & & $\mathrm{x}$ & 300 \\
\hline Doughboy Creek & $\mathbf{X}$ & $\mathbf{X}$ & $\mathbf{X}$ & $\mathbf{X}$ & $\mathbf{X}$ & $\mathbf{X}$ & $\mathbf{X}$ & $\mathbf{X}$ & $\mathbf{X}$ & $\mathbf{X}$ & $\mathbf{X}$ & 511 \\
\hline Healy Creek & $\mathrm{x}$ & $\mathrm{x}$ & $\mathrm{x}$ & $\mathrm{x}$ & $\mathrm{x}$ & $\mathrm{x}$ & $\mathrm{x}$ & & $\mathrm{x}$ & & & 270 \\
\hline Hell Hole Creek & $\mathbf{X}$ & $\mathbf{X}$ & $\mathbf{X}$ & $\mathbf{X}$ & $\mathbf{X}$ & $\mathbf{X}$ & $\mathbf{X}$ & $\mathbf{X}$ & $\mathbf{X}$ & $\mathbf{X}$ & $\mathbf{X}$ & 597 \\
\hline Insulator Creek & $\mathrm{x}$ & $\mathrm{x}$ & $\mathrm{x}$ & $\mathrm{x}$ & $\mathrm{x}$ & $\mathrm{x}$ & $\mathrm{x}$ & & $\mathrm{x}$ & & & 390 \\
\hline Keyatta Lake & $\mathrm{x}$ & & $\mathrm{x}$ & $\mathrm{x}$ & $\mathrm{x}$ & $\mathrm{x}$ & $\mathrm{x}$ & & $\mathrm{x}$ & & & 240 \\
\hline Mud Creek & $\mathrm{x}$ & & $\mathrm{x}$ & $\mathrm{x}$ & $\mathrm{x}$ & $\mathrm{x}$ & $\mathrm{x}$ & & $\mathrm{x}$ & & & 330 \\
\hline Sandfly Creek & $\mathrm{x}$ & & & $\mathrm{x}$ & $\mathrm{x}$ & $\mathrm{x}$ & $\mathrm{x}$ & & $\mathrm{x}$ & & & 268 \\
\hline
\end{tabular}


Trip and Reach. Assemblage structure was analysed using multivariate classification and regression trees (mCARTs). Selection of the final tree models was conducted using 10-fold cross validation, with the 1-SE tree (the smallest tree with cross validation error within $1 \mathrm{SE}$ of that of the tree with the minimum cross validation error) selected as the final tree model, a procedure that produces robust, biologically interpretable trees (Breiman et al. 1984, De'ath 2002). The importance of each variable was evaluated by its occurrence in the final 1-SE tree. Additional trees, up to the size of the minimum SE error tree, were also evaluated to determine what additional information slightly larger models contained.

To investigate the consistency of patterns of change across estuaries, analysis was conducted on unstandardised (absolute) PoE data for those months where samples were available for all estuaries, as well as those for March 2008 when all estuaries except Sandfly Creek were sampled (Table 1). An mCART was constructed using the 26 species that occurred in at least $20 \%$ of Estuary $\times$ Trip $\times$ Reach combinations (Table 2 ). Absolute PoE data produce output sensitive to both species composition and the absolute size of PoE values. Consequently, a second mCART based on PoE standardised by sample totals (relative PoE) was constructed to investigate composition divorced from the influence of overall PoE. In this case, 2 samples would have similar 'composition' if they had the same relative PoE profiles across the species set.

To examine temporal patterns in more detail, additional multivariate analyses were conducted using only data for Crab, Doughboy and Hell Hole Creeks, the sites that could be sampled in all $11 \mathrm{mo}$, and Cocoa Creek that was sampled in all months except October and December 2008. An mCART for absolute PoE was constructed using the 31 species that occurred in at least $20 \%$ of Estuary $\times$ Trip $\times$ Reach combinations (Table 3). Multivariate temporal patterns were summarised in 2-dimensional space on an MDS ordination based on Bray-Curtis distance using Primer 7 software.

Patterns of spatio-temporal change in the PoE for individual species were investigated for the 17 species that occurred in at least $50 \%$ of Estuary $\times$ Trip $\times$ Reach combinations in Crab, Doughboy, Hell Hole and Cocoa Creeks. Individual species patterns were analysed using univariate classification and regression trees (CARTs) with the TreesPlus software (De'ath 2002), again based on the 1-SE criterion. Fish were categorised into one of 3 broad life-history categories, i.e. (1) juveniles of offshore spawning species, (2) estuary spawners, (3) species found in estuaries at all sizes but with unknown spawning locations), based on Robertson and Duke (1990b) and Sheaves \& Johnston (2008).

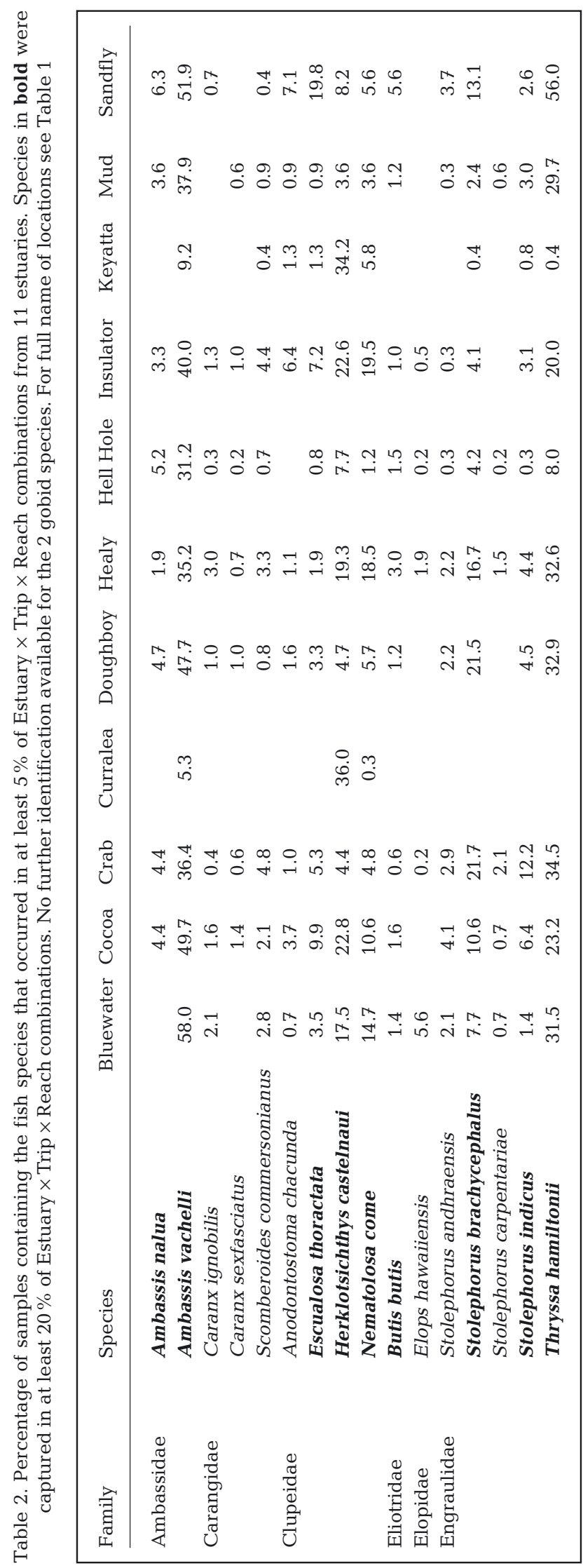




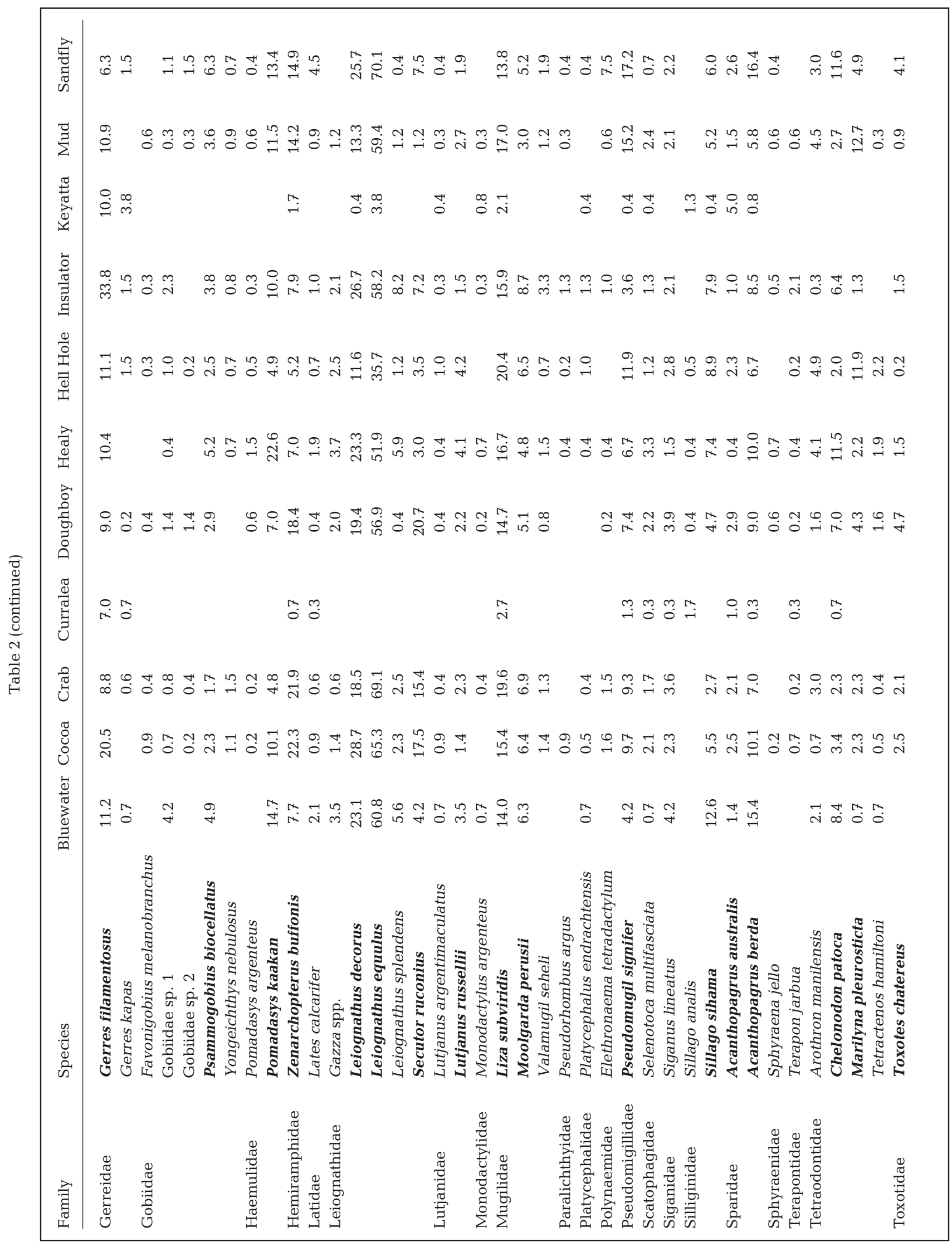


Table 3. Total percentage contribution of fish species occurring in (a) $>50 \%$ and (b) 20 to $49 \%$ of Estuary $\times$ Trip $\times$ Reach combinations to total variable differentiation for estuary nodes and trip nodes in a multivariate classification and regression tree (mCART) for Crab, Doughboy, Hell Hole and Cocoa Creeks over 11 mo. Life-history codes: j-off, juveniles of offshore spawning species; est, estuary spawners; all, species found in estuaries at all sizes but with unknown spawning locations

\begin{tabular}{|c|c|c|c|}
\hline & Estuary & Trip & Life-history \\
\hline \multicolumn{4}{|l|}{ (a) } \\
\hline Leiognathus equulus $^{\mathrm{a}}$ & 22.2 & 16.2 & j-off \\
\hline Liza subviridis & 0.1 & 0.8 & all \\
\hline Ambassis vachelli ${ }^{\mathrm{a}}$ & 6.5 & 21.9 & est \\
\hline Zenarchopterus buffonis & 9.4 & 1.6 & est \\
\hline Thryssa hamiltonii $^{\mathrm{a}}$ & 26.2 & 22.4 & j-off \\
\hline Acanthopagrus berda & 0.1 & 0.1 & est \\
\hline Gerres filamentosus ${ }^{\mathrm{a}}$ & 0.0 & 2.9 & j-off \\
\hline Leiognathus decorus $^{\mathrm{a}}$ & 3.7 & 7.1 & j-off \\
\hline Pseudomugil signifer & 0.0 & 0.6 & est \\
\hline Stolephorus brachycephalus ${ }^{a}$ & 11.5 & 7.8 & j-off \\
\hline Sillago sihama & 0.1 & 0.1 & all \\
\hline Moolgarda perusii & 0.0 & 0.4 & all \\
\hline Herklotsichthys castelnaui & 0.1 & 0.3 & est \\
\hline Pomadasys kaakan & 0.3 & 1.1 & all \\
\hline Marilyna pleurosticta & 2.3 & 0.0 & all \\
\hline Ambassis nalua & 0.0 & 0.1 & est \\
\hline Secutor ruconius ${ }^{\mathrm{a}}$ & 11.5 & 11.4 & j-off \\
\hline \multicolumn{4}{|l|}{ (b) } \\
\hline Chelonodon patoca & 0.5 & 0.4 & all \\
\hline Stolephorus indicus & 1.9 & 0.5 & j-off \\
\hline Nematolosa come & 1.4 & 1.3 & all \\
\hline Psammogobius biocellatus & 0.0 & 0.1 & est \\
\hline Acanthopagrus australis & 0.0 & 0.0 & all \\
\hline Toxotes chatereus & 0.5 & 0.2 & est \\
\hline Escualosa thoractata & 0.8 & 1.0 & j-off \\
\hline Lutjanus russellii & 0.2 & 0.2 & j-off \\
\hline Arothron manilensis & 0.1 & 0.0 & all \\
\hline Scomberoides commersonianus & $s \quad 0.2$ & 0.1 & j-off \\
\hline Butis butis & 0.0 & 0.0 & est \\
\hline Selenotoca multifasciata & 0.0 & 0.4 & all \\
\hline Stolephorus andhraensis & 0.4 & 0.2 & j-off \\
\hline Siganus lineatus & 0.0 & 0.7 & j-off \\
\hline
\end{tabular}

\section{RESULTS}

\section{Physical environment}

Salinity showed the expected seasonal pattern (Fig. 2), with low salinities during the wet season followed by continual increases through the post-wet and dry seasons. Similarly, water temperature (see Fig. S1 in the supplement at www.int-res.com/articles/suppl/ m410p143_supp.pdf) showed a clear seasonal trend with maxima in December 2007 and 2008 and a mini-
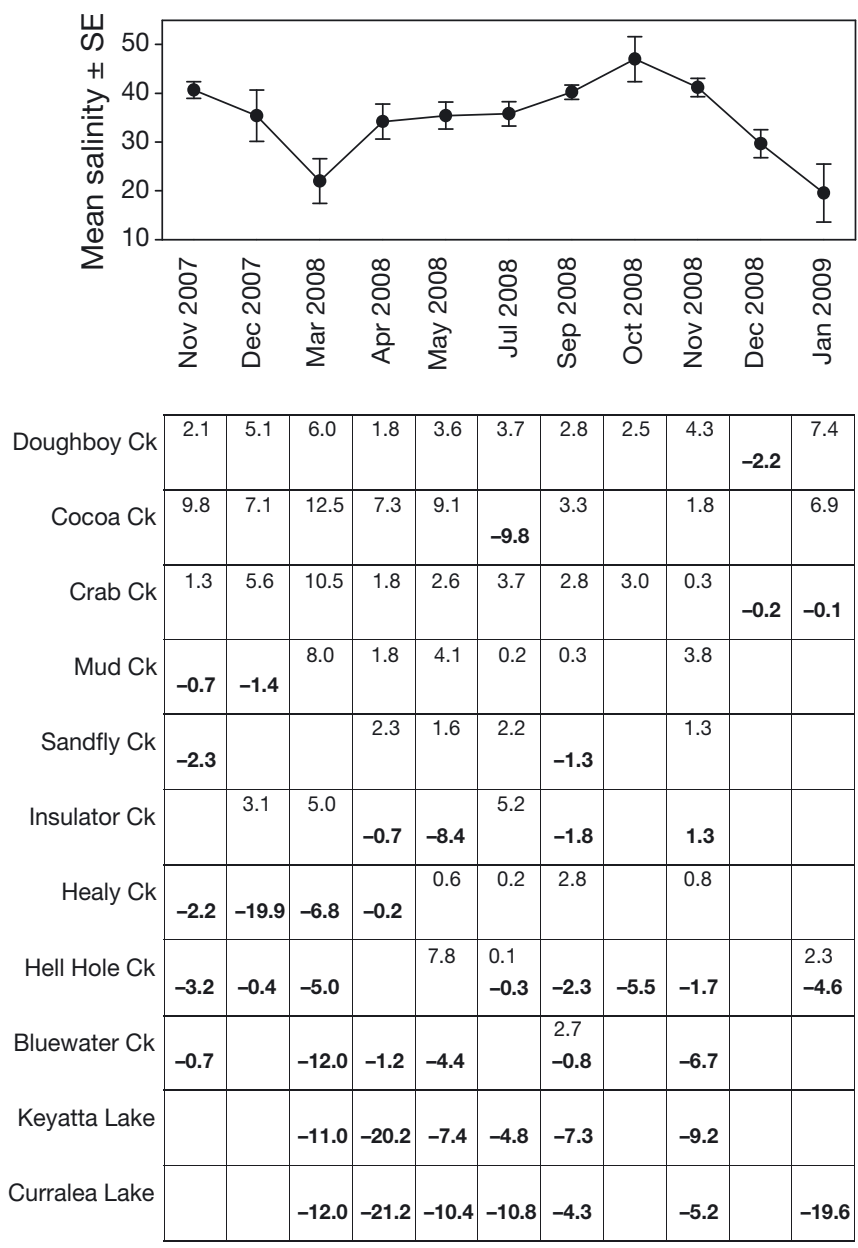

Fig. 2. Mean monthly salinities $( \pm \mathrm{SE})$ calculated from all locations. Table values are deviations from the mean salinity pattern. Estuaries are ranked by the proportion of trips with positive deviations (top of cells) compared to trips with negative deviations (bold, bottom of cells). Ck: Creek

mum in July 2008. Turbidity (see Fig. S2 in the supplement) was more variable, reflecting varying local drivers (e.g. stream flow, tidal action, wind). Salinities at Curralea and Keyatta Lakes were consistently below the overall mean, as were turbidities, but temperatures tended to be intermediate. The ranking of natural estuaries varied among parameters but Hell Hole Creek was notable, with salinity, temperature and turbidity all deviating to lower than average values more consistently than other natural estuaries.

\section{Biological sampling}

Sampling of the 11 estuaries produced 132437 fish from 127 species, 55 of which occurred in at least $5 \%$ of Estuary $\times$ Trip $\times$ Reach combinations (Table 2) 


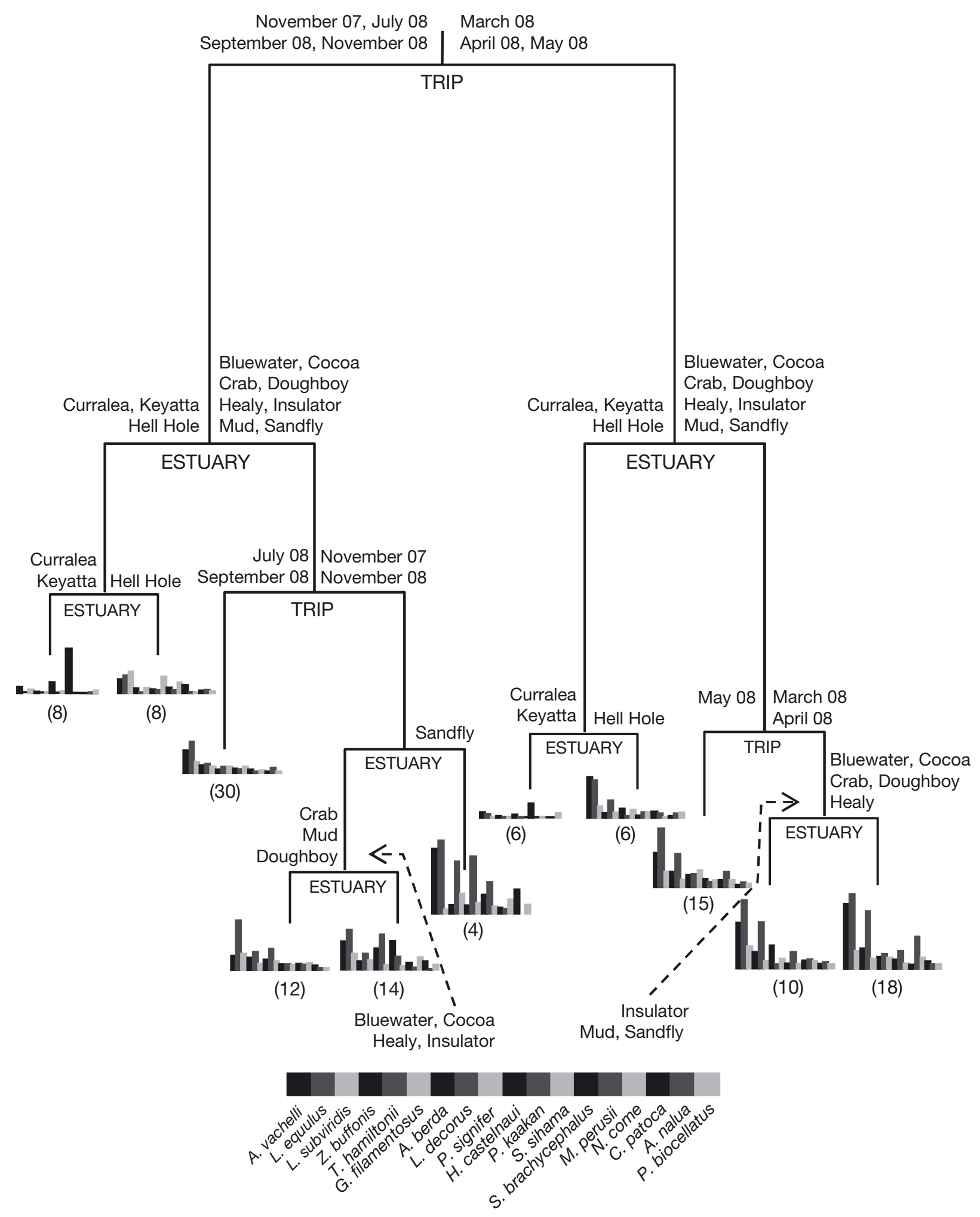

Fig. 3. 1-SE multivariate classification and regression tree (mCART) for absolute probability of encounter (PoE) of fish from 11 estuaries over 7 mo. Upper case text below branches indicates the factor responsible for the split, while lower case text indicates the levels of the factors partitioned to each side of the splits. Numbers in brackets indicate the number of samples in each terminal node. Histograms below terminal nodes indicate the modeled relative PoEs for each species. Only species that occurred in $50 \%$ of Estuary $\times$ Trip $\times$ Reach combinations are shown. For full species names see Table 2 


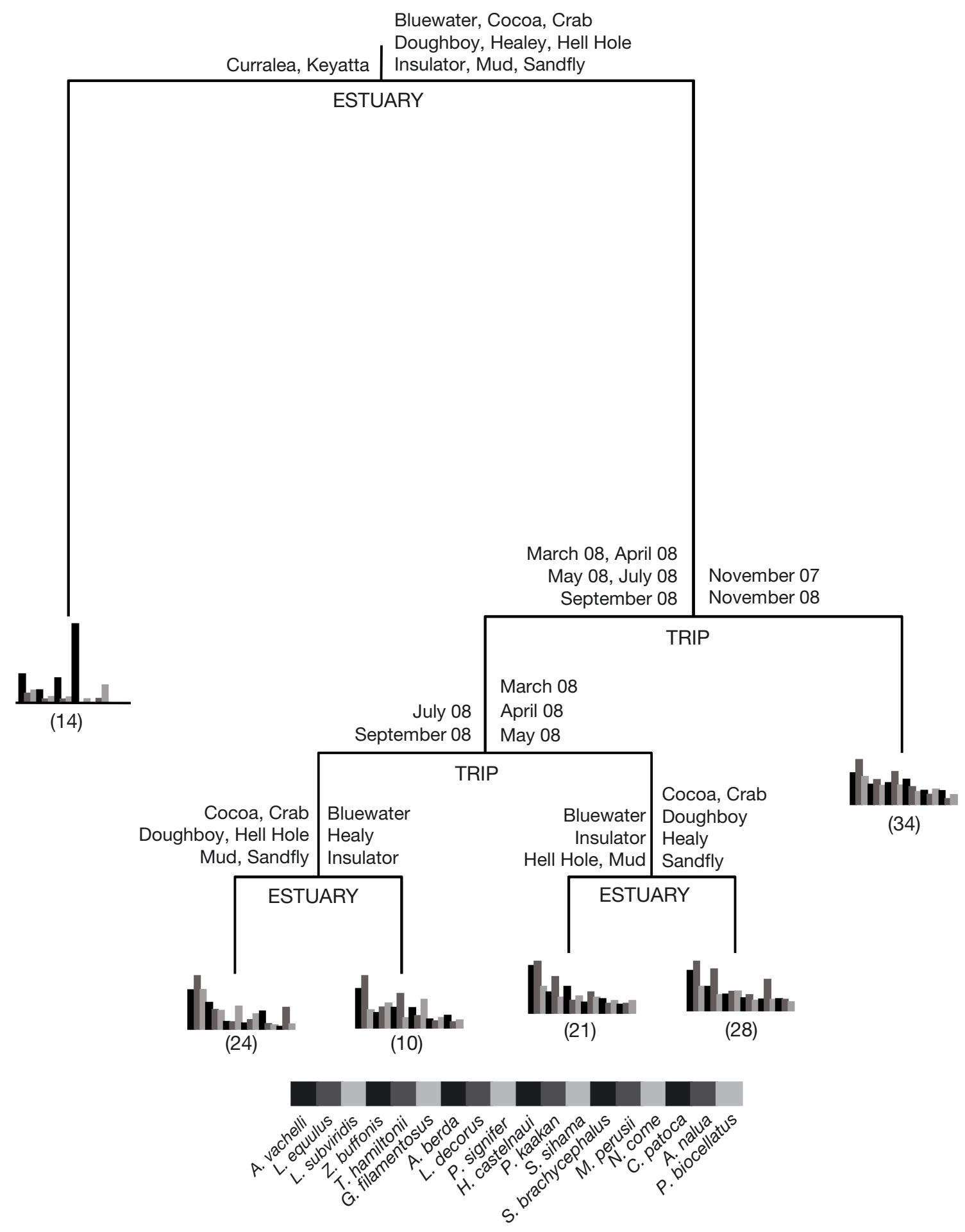

Fig. 4. 1-SE multivariate classification and regression tree (mCART) for relative probability of encounter (PoE) of fish from 11 estuaries over 7 mo. See Fig. 3 for further explanation. For full species names see Table 2

\section{Comparisons among estuaries}

For those months where samples were available for all estuaries (with the exception of Sandfly Creek in March 2008), mCART analysis produced an 11 leaf
1-SE tree for assemblage structure based on absolute PoE that explained $54 \%$ of variability in the data set (Fig. 3). Overall, the tree model showed strong seasonal shifts in PoE and consistent differences among estuaries. An initial Trip split (15\% variability explained) 
partitioned post-wet season samples (with highest PoEs for most species at all sites) from samples for the remainder of the seasons. Identical Estuary splits (total variability explained $16 \%$ ) occurred on both primary branches (i.e. there was no interaction), with PoEs for Curralea and Keyatta Lakes and Hell Hole Creek consistently low relative to the other sites. An additional minor Trip split (9\% explained) separated the higher PoE sites on the left-hand branch into a high PoE prewet season group and a low PoE dry season group, while a minor Trip split on the right-hand branch separated May 2008 samples from the other post-wet season samples. Minor Estuary splits partitioned Hell Hole Creek samples from Curralea and Keyatta Lake samples on both branches (5\% total variability explained), and a final group of Estuary splits broke the remaining estuaries up into a number of groups (9\% total variability explained). Additional splits up to the 18 leaf minimum SE tree simply partitioned the estuaries further, and there were no Reach splits in any mCART models up to the size of the minimum SE tree.

Analysis of relative PoE data for the same samples from all 11 estuaries (33\% variability explained) showed the same temporal structure as absolute PoE but different spatial structure (Fig. 4). Examined as an overall model, the Trip splits are ultimately the same in both trees. July and September initially group with the November samples in Fig. 3 but split from them at the next Trip split, whereas July and September initially group with March, April and May in Fig. 4 before subsequently splitting to form their own group. Consequently, there are 3 distinct groupings of months that are evident in both figures: (1) November 07 and November 08; (2) July 08 and September 08; and (3) March 08, April 08 and May 08. Spatial structure (24\% explained in total) had a much greater influence on composition (i.e. relative PoE) than temporal structure (9\% explained). When relative PoE profiles are considered, Hell Hole Creek no longer groups with Curralea and Keyatta Lakes (initial tree split 18\% variability explained), showing that the grouping of Hell Hole with the Lakes in the absolute PoE tree (Fig. 3) is due to low absolute PoEs and that the species composition at Hell Hole Creek was similar to those of the other 'natural' estuaries. The lakes stand out from all the natural estuaries as having an assemblage dominated throughout the study by the planktivore Herktlotsichthys castelnaui, a species that was relatively unimportant in the natural estuaries, and very low PoEs for species such as Leiognathus equulus, Thryssa hamiltonii, L. decorus, Stolephorus brachycepahlus, and Secutor ruconius, which were common in other estuaries. Trip splits explained $9 \%$ of variability in the data set. Temporal change in composition among the natural estuaries was related largely to changes in pat- terns of dominance. A few species dominated dry season assemblages, with most species having low relative PoEs. The evenness of PoEs was higher in the postwet season and highest in the pre-wet. Assemblage composition was similar across the natural estuaries in the pre-wet season but varied between estuaries during the rest of the study $(6 \%$ additional variability explained by Estuary splits). Cocoa, Crab, Doughboy and Sandfly Creeks grouped together in both dry and post-wet seasons, as did Bluewater and Insulator Creeks. However, allegiances of Healy, Mud and Hell Hole Creeks changed between seasons. Additional splits up to the 12 leaf minimum SE tree again simply further partitioned the Estuary groups, and there were again no Reach splits.

Taken together, the absolute and relative PoE analyses show consistent temporal patterns, overprinting complex spatial differences that are a function of differences in both species compositions and occurrences. The 2 artificial estuarine lakes differed from the natural estuaries in that they showed both attenuated species compositions and low absolute PoEs. In contrast, natural estuaries featured similar suites of species, but within this assemblage differed in both composition (relative PoE) and absolute PoE.

\section{Comparison among estuaries with extended temporal sequences}

Temporal patterns in assemblage structure were examined in detail using data for Crab, Doughboy and Hell Hole Creeks, the sites that could be sampled in all 11 mo, and Cocoa Creek that was sampled in all months except October and December 2008. mCART analysis (Fig. 5) produced a 4 leaf tree (44\% variability explained) that was consistent with the tree constructed for all estuaries (Fig. 3). A primary Trip split (25\% variability explained) segregated a low PoE group composed of the dry season and most of the prewet season (except December) of 2008, from a high PoE group comprising the pre-wet season of 2007, the post-wet season of 2008, December 2008 and the wet season of 2009. Within this group Hell Hole Creek had a low PoE (Estuary split $11 \%$ explained), and there was a final Trip split ( $8 \%$ explained) in the high PoE group of Cocoa, Crab and Doughboy Creeks that separated March and April 2008, and January 2009, from the other months. Again, there were no Reach splits. The main contributors to temporal differences were Leiognathus equulus, Thryssa hamiltonii, L. decorus, Stolephorus brachycephalus and Secutor ruconius, 6 species of offshore spawners only present in the estuaries as juveniles, and the estuary spawner Ambassis vachelli (Table 3). This group, together with the estu- 


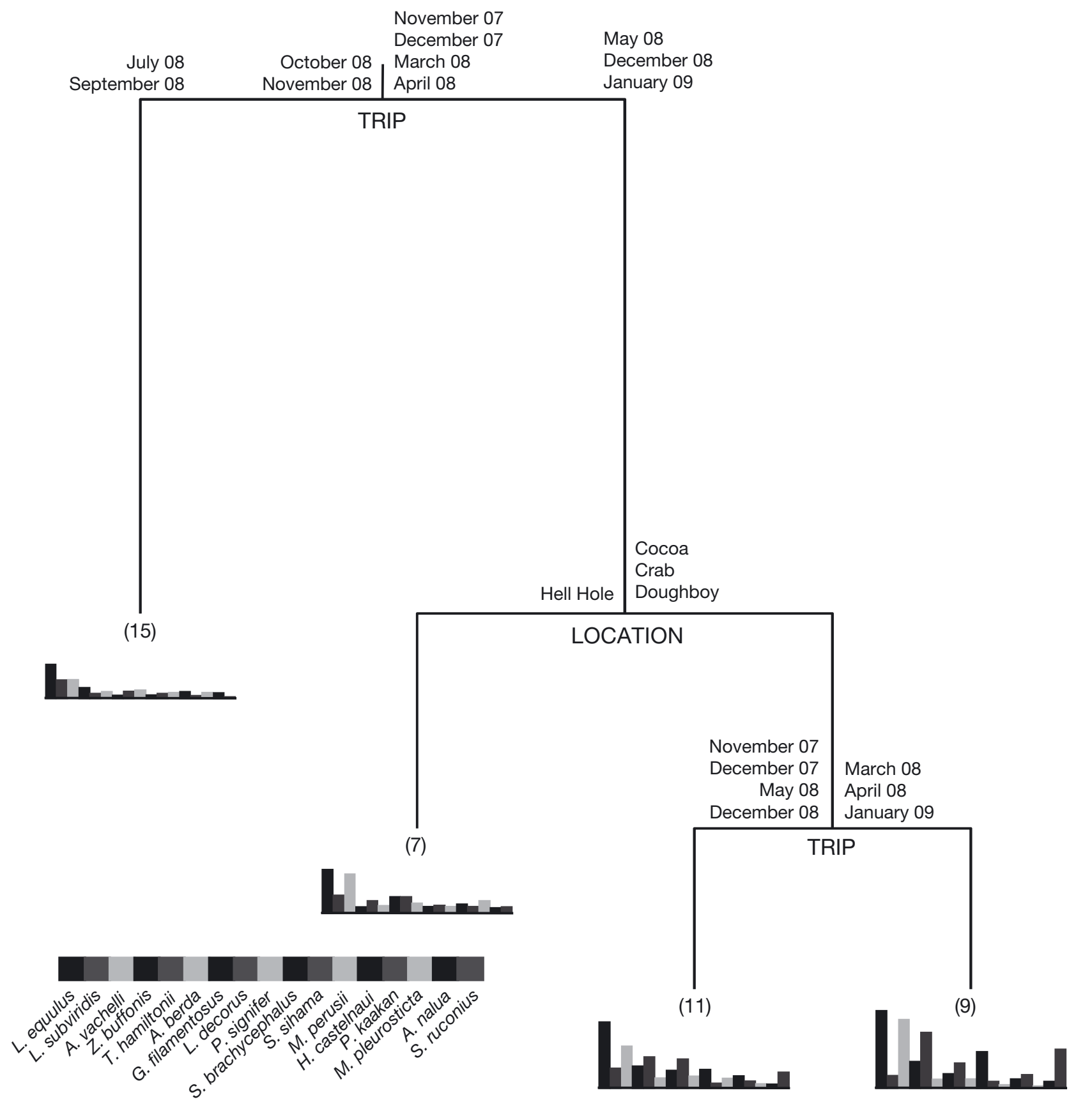

Fig. 5. 1-SE multivariate classification and regression tree (mCART) for absolute probability of encounter (PoE) of fish from 4 estuaries over 11 mo. See Fig. 3 legend for further explanation. For full species names see Table 2

ary-spawning Zenarchopterus buffonis, were the major contributors to spatial differences. Most estuary spawners and species with all life stages present in estuaries contributed little to temporal differences. Strong cyclic trends in assemblage structure that were consistent among estuaries are clear in the MDS ordination (Fig. 6) (stress =0.18). All had similar assemblages in each sampling month, although the difference among estuaries was greater in the dry (e.g. July
2008) and the early pre-wet (e.g. October 2008) seasons, as indicated by larger polygons encompassing months.

Most of the 17 species analysed individually showed clear temporal and/or spatial change. Univariate CART analyses produced valid explanatory models (i.e. 1-SE trees with at least one branching) for 13 individual species' PoEs (Table 4). All demonstrated Trip splits, usually comprising the primary split. There were 


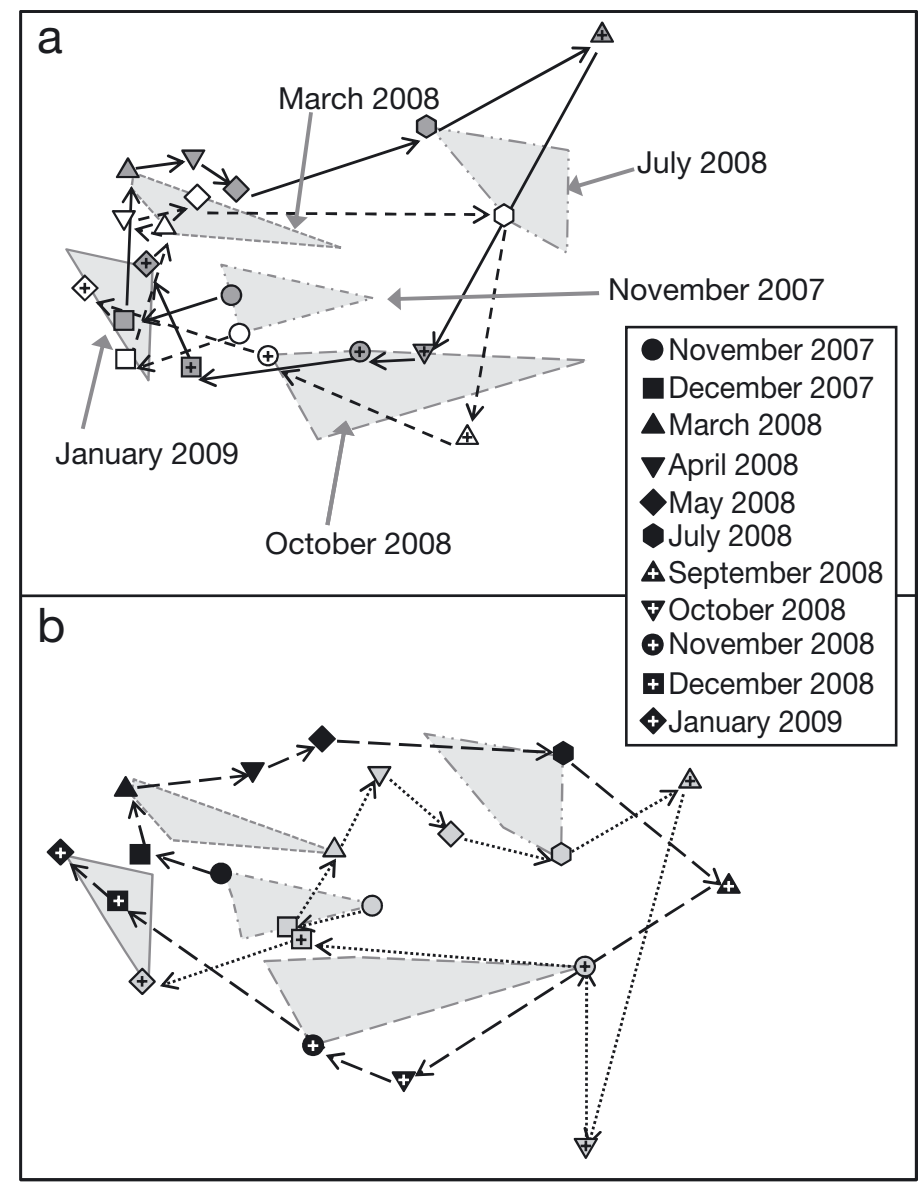

Fig. 6. Two-dimensional mulitdimensional scaling ordination for temporal change in fish assemblage probability of encounter (PoE) in 4 estuaries. The ordination is split for clarity: (a) Crab Creek; dark grey symbols and solid lines; Cocoa Creek, unfilled symbols and dashed lines; (b) Doughboy Creek: black symbols and dashed lines; Hell Hole Creek: light grey symbols and dotted lines. Arrows connecting symbols indicate the direction of temporal change. Grey polygons are repeated on the 2 panels to enhance visual orientation between the panels. Each polygon encompasses the points for all 4 estuaries for 1 of 5 mo, each representative of a particular season: November 2007 (pre-wet); March 2008 (post-wet); July 2008 (dry); October 2008 (pre-wet); January 2009 (wet)

2 clear temporal patterns. Seven species, including the 6 offshore spawners identified as major contributors to the multivariate temporal pattern (Table 3), showed strong seasonality (Table 4a) with high PoEs from the late pre-wet season to the post-wet season, and low dry season and early pre-wet season PoEs. These species displayed a range of strengths in their seasonal patterns. Leiognathus equulus (Fig. 7a) and Zenarchopterus buffonis had PoEs that increased through the pre-wet to peak in the post-wet and then declined to lower levels during the dry season, although they maintained relatively high PoEs throughout the year. Thryssa hamiltonii (Fig. 7b), L. decorus, Gerres fila- mentosus, and Stolephorus brachycephalus showed similar patterns but with PoEs falling to very low levels during the dry season. Secutor ruconius (Fig. 7c) was almost completely absent during the dry season. Ambassis vachelli (Fig. 7d) showed a different pattern, with an additional peak of elevated PoEs in October 2008, during the early pre-wet season. The remaining 5 species lacked clear seasonal patterns, with high PoEs at various times throughout the study (Table $4 \mathrm{~b}$, Fig. $7 \mathrm{e}$ ). Five of the species with strong seasonal patterns showed spatial differences. In each case, PoE was low in Hell Hole Creek and high in at least 2 , but usually all 3, of the other estuaries (Table 4a). Two of the species that lacked clear temporal patterns showed an Estuary effect, with high PoE in 1 of the 3 estuaries (Table 4b).

\section{DISCUSSION}

\section{Consistency of temporal change}

The fish assemblages of the 9 natural estuaries showed consistent patterns of temporal change, despite clear spatial differences in the details of assemblage structure among estuaries. Temporal changes were a function of changes in both absolute PoEs and assemblage compositions. Absolute PoEs for most species were high during the late pre-wet season of 2007 and the post-wet season of 2008, and then declined to be lowest in the dry season before returning to high levels during the succeeding pre-wet season. This sequence of change matches that recorded in Alligator Creek, a nearby tropical estuary (Robertson \& Duke 1990a) and is in line with the strong assemblage differences between dry and prewet seasons from 9 other tropical estuaries in Sheaves' (2006) less temporally explicit study. Such findings are consistent with patterns attributed to seasonal recruitment of offshore spawning species into estuaries in the USA (Greenwood et al. 2007, Rozas et al. 2007) and Europe (Ramos et al. 2006). In the present study, assemblage composition changed in a parallel way to absolute PoEs in the natural estuaries. Relative PoE profiles were dominated by a few species in the dry season and became progressively more even through the post-wet to pre-wet seasons. In contrast, although similar to each other, the 2 constructed estuaries maintained quite different assemblages to those of the natural estuaries. Here, temporal differences related only to absolute PoEs, with assemblage composition remaining similar over time. 
Table 4. Univariate classification and regression tree (CART) results for probability of encounter (PoE) of species for which valid models could be produced. (a) Species with strong seasonality, (b) species without strong seasonality. Left-hand part of table shows tree-fitting statistics and the factors responsible for the first 2 tree splits. Centre of table indicates groupings identified from Trip splits with high (dark grey shading) and low (white) PoE. Where 3 Trip groups were formed, the groups with the highest PoE are shaded dark grey and intermediate PoE light grey. Right-hand column indicates which estuaries had high PoE for species with location splits. Split codes: tr, Trip; est, Estuary. Ck: Creek. For full species names see Table 2

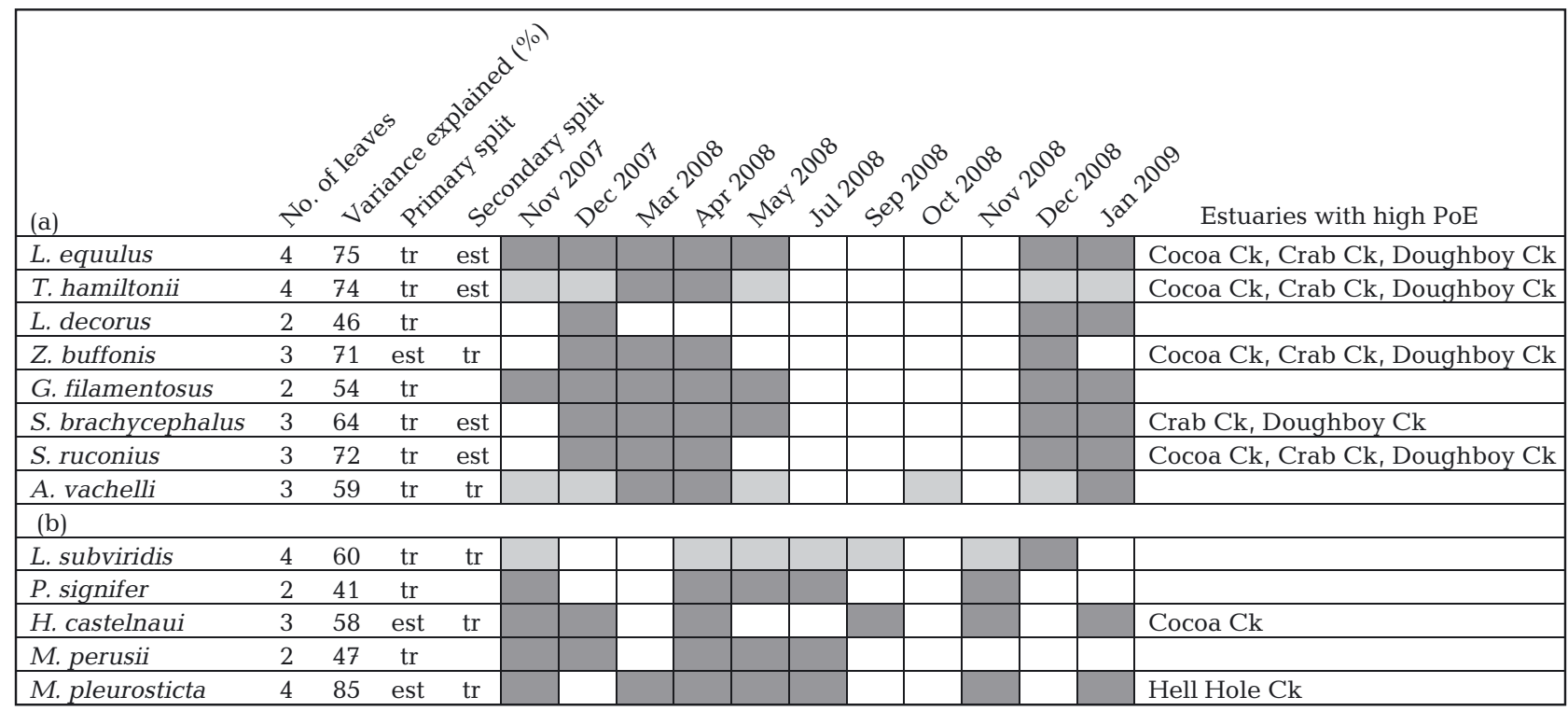

\section{Spatial differences}

Spatial differences in assemblage structure were complex, involving both differences in species composition and differences in absolute PoE. The 2 constructed estuarine lakes differed from the natural estuaries in that they both had low absolute PoEs and attenuated species composition dominated by a single species, the planktivore Herklotsichthys castelnaui. Restricted access channels and a history of high levels of phytoplankton and eutrophication-driven fish kills in these lakes (Sheaves \& Johnston 2010) probably accounts for the dominance of planktivores and the restricted fauna. In contrast to the constructed estuaries, the assemblages of natural estuaries comprised species mixes similar to those of previous studies (e.g. Blaber 1980, Robertson \& Duke 1987, Sheaves \& Johnston 2009) but differed in details of both composition and absolute PoE. The most extreme case was Hell Hole Creek, where species compositions were similar to those in other natural estuaries but absolute PoEs remained extremely low throughout the study. The consistently low PoEs in Hell Hole Creek are difficult to explain. It possessed no obvious geomorphological differences or apparent levels of stressors that would set it apart from the other natural estuaries. However, the physical environment of Hell Hole Creek was among the most extreme of the natural systems, with salinities, temperatures and turbidities all deviating to lower than average values more consistently than the other natural estuaries.

\section{Drivers of temporal change}

The high PoEs in the pre- to post-wet season are consistent with the high recruitment and growth seasons for juveniles of offshore spawning species (Robertson \& Duke 1990b, Sheaves 2006). In fact, with the exception of the common estuary resident Ambassis vachelli, the main contributors to temporal differences in assemblage structure in the present study were offshore spawning species that use estuaries as nursery grounds. Consequently, assemblage change was intimately linked to nursery ground function, driven by the cycle of recruitment, growth and subsequent emigration that underpins it. The importance of offshore spawned fish to temporal patterns implies that offshore-estuary connectivity is a key force regulating assemblage structure and driving ecosystem processes, and/or that the seasonal changes in the occurrence of offshore spawners are a response to seasonally variable drivers (Barletta et al. 2005, Gewant \& Bollens 2005, Love \& May 2007). These 2 possibilities are difficult to separate, and are probably both valid. For instance, Robertson \& Duke (1990a) suggest that a high density of new recruits is a response to food availability, related to high abundances of brachyuran 


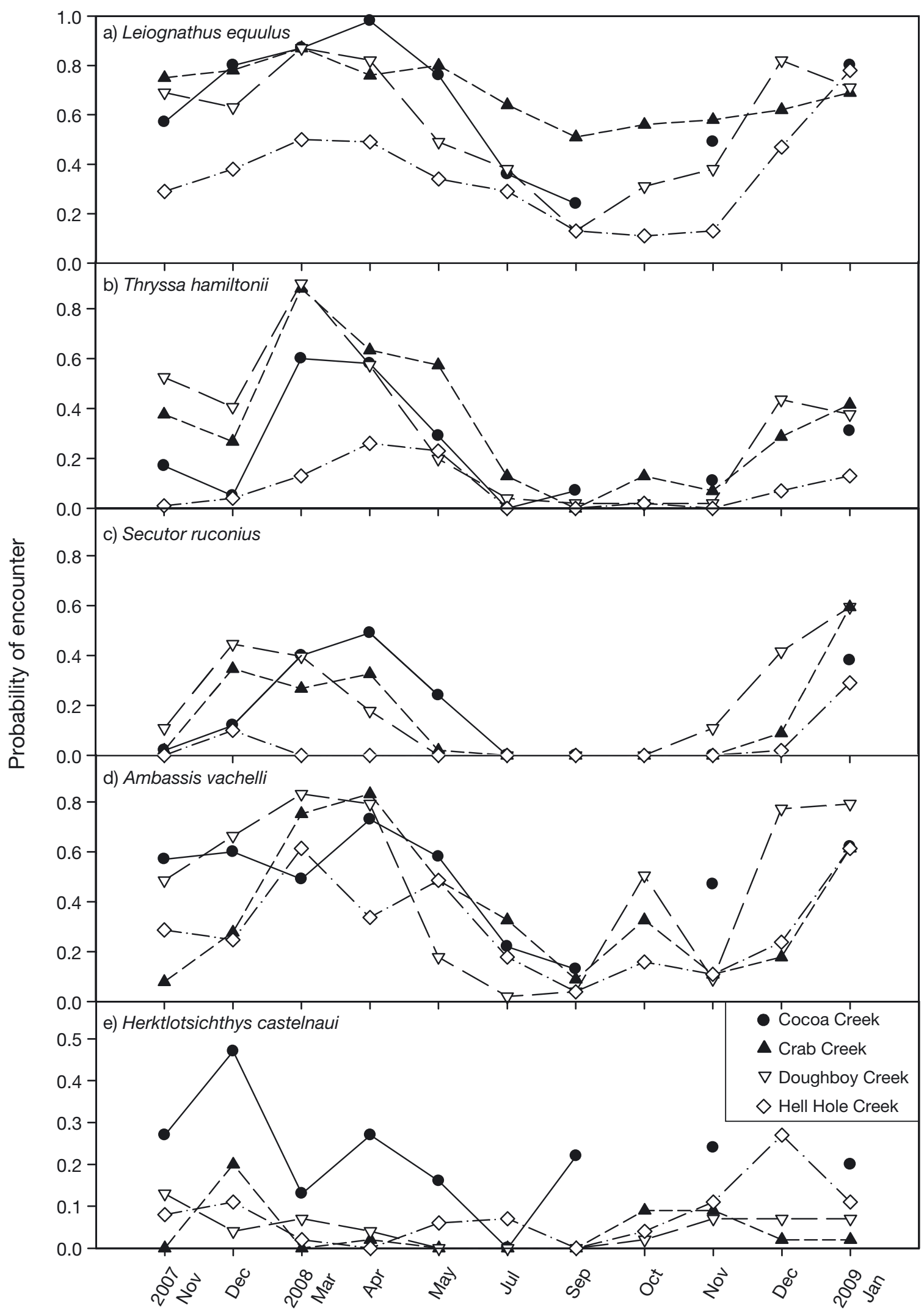

Fig. 7. Probability of encounter (PoE) profiles over time for 5 species from 4 estuaries. Note that months with no data are omitted from the temporal sequence on the $x$-axis 
megalopae during the pre-wet and wet seasons (Robertson et al. 1988), which may also link to seasonal changes in the importance of terrestrially derived nutrient inputs to tropical estuaries (Abrantes 2008). In this context recruitment could be seen as a response to predictable changes in the nutrient-prey spectrum or, equally validly, ocean-estuary connectivity could be seen as a driver enabling recruiting fish to access key resources when they are available and facilitating targeted predation that controls crab recruitment. The process outcomes of these seasonal changes can be complex. For example, seasonal peaks in the occurrence of recruiting fish trigger temporary shifts in the diets of non-predatory species to feed on small fish, thereby producing rapid changes in total predation pressure on new recruits (Baker \& Sheaves 2005, 2009). Thus, seasonal events simultaneously regulate prey species recruitment success and population sizes, trigger a functional response in non-predatory species, provide a nutritive boost that supports populations of non-predatory species, and produce temporal shifts in food web structure.

While the nursery ground function of natural tropical estuaries (Robertson \& Duke 1987) is intimately intertwined with temporal changes in assemblage structure, this did not seem to be the case for the 2 artificial estuarine lakes. Whereas assemblage structure in the natural estuaries responded to the temporal cycle, assemblage compositions in Curralea and Keyatta Lakes were stable over time. Added to this, the key species involved in temporal dynamics in the natural estuaries had very low PoEs in the lakes throughout the study. The planktivore Herklotsichthys castelnaui dominated the lakes throughout the study, probably a reflection of the high phytoplankton densities that prevail there (Sheaves \& Johnston 2010). Clearly, the natural estuaries and the poorly connected artificial lakes differ significantly at an assemblage level, and by implication at a process level, with substantial differences in species composition indicating quite different food web structures. Taken together, the restricted connectivity (Rozas 1992), restricted circulation (Maxted et al. 1997) and poor water quality (Baird \& Pereyra-Lago 1992, Maxted et al. 1997) typical of many artificial waterways probably diminishes their value as nursery grounds for many species. Although the proliferation of artificial waterways around the world has the potential to provide expanded amounts of estuarine habitat available to fish (Baird et al. 1981, Morton 1992) and to replace degraded habitat, unless modification is managed much more carefully than in Keyatta and Curralea Lakes the outcome is likely to be diminished fish habitat quality, reduced fisheries production and degraded ecosystem function.

\section{CONCLUSIONS}

Pattern and process are intimately interlinked in tropical estuaries; the recruitment cycle (process) drives temporal changes fish in assemblages (pattern), which provide the raw material (species composition) that determines the specific characters and functioning of critical ecosystem processes like food web dynamics and predation. Multiscale connectivity is the key process facilitating this complex interlinking. It is the factor that determines the pattern of larval supply and subsequently assemblage composition and allows a multitude of complex interactions to shape patterns of change over time (Sheaves 2009). For instance, the pattern of recent recruitment is critical in determining the suite of predators which new recruits will encounter, because settled juveniles are often the major predators of recruiting fish in tropical estuaries (Baker \& Sheaves 2005). Additionally, the predictability of recruitment allows specialised predators to target specific locations and times when prey are predictably abundant (Juanes \& Conover 1995, Willson \& Womble 2006, Whitfield et al. 2008), thus focusing predation pressure on new recruits and recruitment events. The contrast between the clear patterns of change in natural systems and the attenuated fauna and lack of temporal change in the poorly connected artificial estuaries shows that ensuring the integrity of biological connectivity is critical to maintaining normal patterns of temporal change and, by implication, of ecological functioning.

Acknowledgements. This project was supported by a grant from the Marine and Tropical Sciences Research Facility. We thank Ashlee Johnson and the many volunteers whose assistance made the extensive fieldwork possible. This work was conducted in accordance with institutional, national and international guidelines concerning the use of animals in research under ethics permit A1210 issued by James Cook University.

\section{LITERATURE CITED}

Abrantes K (2008) Trophic structure and the importance of terrestrial wetland producers for aquatic food webs in tropical Australian estuaries. PhD thesis, James Cook University, Townsville

Abrantes K, Sheaves M (2008) Incorporation of terrestrial wetland material into aquatic food webs in a tropical estuarine wetland. Estuar Coast Shelf Sci 80:401-412

Baird D, Pereyra-Lago R (1992) Nutrient status and water quality assessment of the Marina Glades canal system, Kromme Estuary, St. Francis Bay. Water SA 18:37-42

Baird D, Marais JFK, Wooldridge T (1981) The influence of a marina canal system on the ecology of the Kromme estuary, St. Francis Bay. S Afr J Zool 16:21-34

Baker R, Sheaves M (2005) Redefining the piscivore assemblage of shallow estuarine nursery habitats. Mar Ecol Prog Ser 291:197-213 
Baker R, Sheaves M (2009) Refugees or ravenous predators: detecting predationon new recruits to tropical estuarine nurseries. Wetlands Ecol Manag 17:317-330

Barletta M, Barletta-Bergan A, Saint-Paul U, Hubold G (2005) The role of salinity in structuring the fish assemblages in a tropical estuary. J Fish Biol 66:45-72

Blaber SJM (1980) Fish of the Trinity Inlet system of north Queensland with notes on the eology of fish faunas of tropical Indo-Pacific estuaries. Aust J Mar Freshw Res 31:137-146

> Blaber SJM, Brewer DT, Salini JP (1989) Species composition and biomasses of fishes in different habitats of a tropical northern Australian estuary: their occurrence in the adjoining sea and estuarine dependence. Estuar Coast Shelf Sci 29:509-531

BOM (Australian Bureau of Meterology) (2009) Townsville, Queensland Daily Weather Observations. Australian Department of Environment, Water, Heritage and the Arts Canberra. www.bom.gov.au/climate/dwo/IDCJDW4128. latest.shtml

Breiman L, Friedman J, Olshen R, Stone C (1984) Classification and regression trees. Wadsworth Internation Group, Belmont

> Cyrus DP, Blaber SJM (1992) Turbidity and salinity in a tropical northern Australian estuary and their influence on fish distribution. Estuar Coast Shelf Sci 35:545-563

De'ath G (2002) Multivariate regression trees: a new technique for modeling species-environment relationships. Ecology 83:1105-1117

Deegan LA (1993) Nutrient and energy transport between estuaries and coastal marine ecosystems by fish migration. Can J Fish Aquat Sci 50:74-79

> Gewant DS, Bollens SM (2005) Macrozooplankton and micronekton of the Lower San Francisco Estuary: seasonal, interannual, and regional variation in relation to environmental conditions. Estuaries 28:473-485

Greenwood MFD, Matheson RE, McMichael RH, MacDonald TC (2007) Community structure of shoreline nekton in the estuarine portion of the Alafia River, Florida: differences along a salinity gradient and inflow-related changes. Estuar Coast Shelf Sci 74:223-238

> Johnston R, Sheaves M (2008) Cross-channel distribution of small fish in tropical and subtropical coastal wetlands is trophic-, taxonomic-, and wetland depth-dependent. Mar Ecol Prog Ser 357:255-270

> Juanes F, Conover DO (1995) Size-structured piscivory: advection and the linkage between predator and prey recruitment in young-of-the-year bluefish. Mar Ecol Prog Ser 128:287-304

> Ley JA (2005) Linking fish assemblages and attributes of mangrove estuaries in tropical Australia: criteria for regional marine reserves. Mar Ecol Prog Ser 305:41-57

> Ley JA, Halliday IA, Tobin AJ, Garrett RN, Gribble NA (2002) Ecosystem effects of fishing closures in mangrove estuaries of tropical Australia. Mar Ecol Prog Ser 245:223-238

> Love JW, May EB (2007) Relationships between fish assemblage structure and selected environmental factors in Maryland's coastal bays. Northeast Nat 14:251-268

Manley PN, Zielinski WJ, Schlesinger MD, Mori SR (2004) Evaluation of a multiple-species approach to monitoring species at the ecoregional scale. Ecol Appl 14:296-310

> Maxted JR, Eskin RA, Weisberg SB, Chaillou JC, Kutz FW (1997) The ecological condition of dead-end canals of the Delaware and Maryland coastal bays. Estuaries 20: 319-327

$>$ Morton RM (1992) Fish assemblages in residential canal

Editorial responsibility: Jana Davis,

Annapolis, Maryland, USA developments near the mouth of a subtropical Queensland estuary. Aust J Mar Freshw Res 43:1359-1371

Ramos S, Cowen RK, Re P, Bordalo AA (2006) Temporal and spatial distributions of larval fish assemblages in the Lima estuary (Portugal). Estuar Coast Shelf Sci 66:303-314

> Robertson AI, Duke NC (1987) Mangroves as nursery sites: comparisons of the abundance and species composition of fish and crustaceans in mangroves and other nearshore habitats in tropical Australia. Mar Biol 96:193-205

> Robertson AI, Duke NC (1990a) Recruitment, growth and residence time of fishes in a tropical Australian mangrove system. Estuar Coast Shelf Sci 31:723-743

Robertson AI, Duke NC (1990b) Mangrove fish-communities in tropical Queensland, Australia: spatial and temporal patterns in densities, biomass and community structure. Mar Biol 104:369-379

Robertson AI, Dixon P, Daniel PA (1988) Zooplankton dynamics in mangrove and other nearshore habitats in tropical Australia. Mar Ecol Prog Ser 43:139-150

Rozas L (1992) Comparison of nekton habitats associated with pipeline canals and natural channels in Louisiana salt marshes. Wetlands 12:136-146

Rozas LP, Minello TJ, Zimmerman RJ, Caldwell P (2007) Nekton populations, long-term wetland loss, and the effect of recent habitat restoration in Galveston Bay, Texas, USA. Mar Ecol Prog Ser 344:119-130

Sheaves MJ (1996a) Habitat-specific distributions of some fishes in a tropical estuary. Mar Freshw Res 47:827-830

Sheaves M (1996b) Do spatial differences in the abundance of 2 serranid fishes in estuaries of tropical Australia reflect long-term salinity patterns? Mar Ecol Prog Ser 137:39-49

Sheaves M (1998) Spatial patterns in estuarine fish faunas in tropical Queensland: a reflection of interaction between long-term physical and biological processes? Mar Freshw Res 49:31-40

Sheaves MJ (2006) Scale-dependent variation in composition of fish fauna among sandy tropical estuarine embayments. Mar Ecol Prog Ser 310:173-184

Sheaves M (2009) Consequences of ecological connectivity: the coastal ecosystem mosaic. Mar Ecol Prog Ser 391: 107-115

Sheaves M, Johnston R (2008) Influence of marine and freshwater connectivity on the dynamics of subtropical estuarine wetland fish metapopulations. Mar Ecol Prog Ser 357:225-243

Sheaves M, Johnston R (2009) Ecological drivers of spatial variability among fish fauna of 21 tropical Australian estuaries. Mar Ecol Prog Ser 385:245-260

Sheaves M, Johnston R (2010) Implications of spatial variability of fish assemblages for monitoring of Australia's tropical estuaries. Aquat Conserv: Mar Freshw Ecosyst 20: 348-356

- Sheaves M, Johnston R, Abrantes K (2007) Fish fauna of dry sub-tropical estuarine floodplain wetlands. Mar Freshw Res 58:931-943

Whitfield AK, Adams JB, Bate GC, Bezuidenhout K and others (2008) A multidisciplinary study of a small, temporarily open/closed South African estuary, with particular emphasis on the influence of mouth state on the ecology of the system. Afr J Mar Sci 30:453-473

Willson MF, Womble JN (2006) Vertebrate exploitation of pulsed marine prey: a review and the example of spawning herring. Rev Fish Biol Fish 16:183-200

Wilson J, Sheaves M (2001) Short-term temporal variations in taxonomic composition and trophic structure of a tropical estuarine fish assemblage. Mar Biol 139:787-796

Submitted: January 18, 2010; Accepted: May 10, 2010

Proofs received from author(s): July 5, 2010 